ÇOMÜ Uluslararası Sosyal Bilimler Dergisi 4(1), 101-110, 2019

COMU International Journal of Social Sciences 4(1), 101-110, 2019

\title{
Ceramic Braziers From Çanakkale
}

\begin{abstract}
The vessels likely to be identified as braziers or portable hearths are instruments which were shaped in agreement with the controlled use of fire. Thanks to these hearths, in which the charcoal in glowing state probably obtained from a burning hearth was used, foods or beverages could be cooked or could preserve their heat throughout a meal. Examples of the portable terracotta braziers are known in Anatolia starting from the early periods. The terracotta braziers, numerous examples of which were discovered at many centers such as Miletus, Pergamum, Athens, Corinth, and Paphos, are understood to have been used widely throughout the Archaic, Classical, and Hellenistic periods. However, their examples, dated to the late Roman and Byzantine periods, are relatively fewer. An evaluation of the ceramic brazier examples which are surveys were carried out on the valleys that reached the Hellespont and in their surrounding areas will constitute the subject of this study.
\end{abstract}

Keywords: Çanakkale, Ceramic, Brazier, Scepsis, Üstünlü.

\section{Çanakkale'den Seramik Mangallar}

Öz

Mangal ya da taşınabilir ocaklar olarak tanımlanabilecek kaplar ateşin kontrollü bir biçimde kullanılmasına uygun biçimlendirilmiş araçlardır. Olasılıkla yanan bir ocaktan alınan kor halindeki odun kömürünün kullanıldığı bu ocaklar sayesinde yiyecek ya da içeceklerin pişirilmesi ya da yemek boyunca ısısını muhafaza etmesi sağlanırdı. Taşınabilir pişmiş toprak mangalların örnekleri Anadolu'da erken dönemlerden itibaren bilinir. Milet, Bergama, Atina, Korinth, Paphos gibi birçok merkezde çok sayıda örneği tespit edilen pişmiş toprak mangalların Arkaik, Klasik ve Hellenistik dönem boyunca yaygın biçimde kullanıldığı anlaşılır. Geç Roma ve Bizans dönemine tarihlenen örnekleri ise görece daha azdır. Bu çalışmada Çanakkale Boğazı'na ulaşan vadiler ve çevresindeki alanlarda Bizans Dönemi yerleşimlerinin tespit edilmesi ve belgelenmesi amacıyla yürüttüğümüz yüzey araştırmalarında tespit ettiğimiz ve belgelediğimiz seramik mangalların değerlendirilmesi amaçlanmıştır.

Anahtar Kelimeler: Çanakkale, Seramik, Mangal, Kurşunlu, Üstünlü.

Prof. Dr., Çanakkale Onsekiz Mart Üniversitesi, ayseturker@comu.edu.tr 
To determine the settlements of the Byzantine period and understand the settlement models on the valleys reaching the Hellespont and in the surrounding areas, surveys are conducted in the settlements on both shores of the Hellespont by us. Significant and numerous finds belonging to the settlements of the Byzantine period are detected in these surveys ${ }^{1}$. The ceramic finds to contribute to our understanding of the everyday life in the Byzantine period are one of the important groups among the finds. An evaluation of the ceramic brazier examples will constitute the subject of this study.

The vessels likely to be identified as braziers or portable hearths are instruments which were shaped in agreement with the controlled use of fire. Thanks to these hearths, in which the charcoal in glowing state probably obtained from a burning hearth was used, foods or beverages could be cooked or could preserve their heat throughout a meal. Examples of the portable terracotta braziers are known in Anatolia starting from the early periods. An example discovered at Pulur in the Keban region at the layer dated to the first half of $3000 \mathrm{BC}$ is in the form of a tray with raised edges ${ }^{2}$. In fact, braziers or portable hearths are known to lack a very complicated order. From some publications in the 19th century, it is understood that large plates or shallow bowls were used with a function as braziers ${ }^{3}$. On the other hand, Mingazzini names the vessels of an analogous type as bracierit. When naming these vessels as braziers, he takes into consideration the carbonized substances he detected inside the vessels. At the same time, the bronze artifacts with an analogous shape also formed data which supported this finding ${ }^{5}$.

1 For some publications on these studies, see. A. Ç. Türker, "Byzantine Pottery from the Pegai Castle", $\mathrm{Xt}^{\text {th }}$ Congress AIECM3 on Medieval and Modern Period Mediterranean Ceramics Proceedings, 19-24 October Antalya Vol 1, VEKAM 2018a, pp. 371-382; A. Ç. Türker, "Çanakkale Boğazı ve Çevresindeki Bizans Limanları: Üstünlü Limanı", Uluslararası Propontis ve Çevre Kültürleri Sempozyumu, Tarihöncesi Çağlardan Antik Dönem Sonuna Kadar, 15-19 Ekim 2018, Biga- Çanakkale (in print); A. Ç. Türker, "Stands From Üstünlü Port", LRCW 6, 6th International Conference on Late Roman Coarse Ware, Cooking Ware and Amphorae in the Mediterranean: Archaeology and Archaeometry Land and sea: pottery routes, Agrigento, 24-28 maggio 2017 (in print); A. Ç. Türker, "Byzantine Pottery From Hexamilion on the Thracian Chersonese", AIECM 3, $12^{\text {th }}$ Congress on Medieval and Modern Period Mediterranean Ceramics, 21-27 Ekim 2018, Atina (in print); "Byzantine Pottery from Dardanos and Kepez in the Hellespontus" The Deltion of the Christian Archaeological Society,33, 2013a, pp. 361-374; "Two Byzantine Cities in the middle section of the Dardanelles: Madytos and Koila" Episcopus, ciuitas, territoriumunun, Città del Vaticano 2013, Acta XVth Congressus Internationalis Archaeologiae Cristianae, Toledo, 8-12.9.2008 (Ed. O. Brandt -S. Cresci, J. López Quiroga- C. Pappalardo), Città del Vaticano 2013b, pp. 105-119.

2 For this example and the examples from Kültepe, Beycesultan, and Boğazköy, see. R. Naumann, Eski Anadolu Mimarlığı, Ankara 1991, p.193, fig. 231.

3 Pottier, (1897) names as "Grand plat creux", while Urtwangler (1885) and Masner (1892) names as "schüssel" see. Lisa C. Pieraccini, Around the Hearth, Caeratan Cylinder Stamped Braziers, Roma 2003, 161. In addition see. J. H. C. Kern, "A Roman Terra Sigillata Dish From Tunisia, in Leyden”, Mnemosyne, Fourth series, vol. 11, fasc. 2, 1958, pp.152-156. P. Mingazzini, Vasi della colleziione Castellani. Catalogo, Rome 1930, p. 70.

5 The words puraunos, chutropous, Isana, bauno and eschara are found out to have been used for a brazier in Ancient Greece. In the classical period, eschara indicated a kind of altar or only its upper section, where the fire burned. See G. Ekroth, Altars on Attic Vases: The Identification of Bomos and Eschara. In Ceramics in context, Proceedings of the Internordic Colloquium on Ancient Pottery held at Stockholm, ed. C. Scheffer, Stockholm 2001, pp. 115-126. It has been determined that the word eschara was used to identify cooking utensils in the 2 nd century AD. See B. A. Sparkes, The Greek Kitchen, The Journal of Hellenic Studies, 82, 1962, pp. 121-137. In addition, for the terminology of braziers and their ways of use, see Lisa C. Pieraccini, 2003, p. 161 et al.; M. E. Snodgrass, Encyclopedia of Kitchen History, New York 2004, pp. 106-107. 
On the other hand, the braziers unearthed at the layers dated to the 1st century during the excavations at the Athenian Agora consist of a semicylindrical unit fixed onto a wide tray with a low base. This semicylindrical unit functions as a stand for the vessels which would be placed onto it. In this way, the vessels were not placed directly onto the embers but onto a semicylindrical unit which functioned as a hearth fed by the embers. Similarly, a terracotta brazier consisting of a semicylindrical unit and the ember removal tray in front of it was also determined among the finds from Cnidus ${ }^{6}$. This example is dated to the period between the late 2 nd century and the mid-1st century BC considering its similarity to a brazier at Bodrum Archaeology Museum ${ }^{7}$. The terracotta braziers, numerous examples of which were discovered at many centers such as Miletus, Pergamum, Athens, Corinth, and Paphos, are understood to have been used widely throughout the Archaic, Classical, and Hellenistic periods ${ }^{8}$.

However, their examples, dated to the late Roman and Byzantine periods, are relatively fewer ${ }^{9}$. The failure to see the examples detected during the excavations at Agora after the 1st century is accounted for by the fall in the prices of metal braziers and by the fact that they became common accordingly ${ }^{10}$. Nevertheless, an example found in Thessaloniki, preserved at the Thessaloniki Museum of Byzantine Culture, and dated to the $3 r d-4$ th centuries shows that the use of portable terracotta hearths continued ${ }^{11}$. Unlike the others, this example was provided with a cylindrical unit on both sides of the semicylindrical section located at the center and has an arrangement on which three different vessels could be placed simultaneously. The items of the 5 th-6th centuries detected in the studies during the excavations at Sardis ${ }^{12}$, Knossos $^{13}$, Tunisia ${ }^{14}$, and the Vinalopó Valley ${ }^{15}$ in Spain as well as of the 9th-10th centuries detected in the studies during the

6 E. Aslan, "2014 Yılı Knidos Sualth Araştırmalarında Elde Edilen İlk Bulguların Değerlendirilmesi" Mediterrenean Journal of Humanities, 1, 2015, pp. 101-123, esp. 108, fig. 2.6.

7 Metallic examples of the Roman period for these terracotta braziers are also known. see. D. Ashkenazi - M. Fischer - A. Stern O. Tal, "Technology of an ancient ship brazier, a unique example from the southern Levant", Skyllis, 12, 2012, heft. 1, pp. 85-93.

8 For Milet see. A. Aydemir, "Funde aus Milet XX. Kochgeschirr und Küchengeräte aus dem archaischen Milet", Archäologischer Anzeiger 2005/2, pp. 85-101. For Pergamon see. W. Radt, "Pergamon. Vorbericht über die Kampagne 1979", TürkAD 26-1, 1982, pp. 11-25, Lev. 10. For an evaluation of the examples of the Hellenistic period and of their production centers, see. M. Şahin, "Bodrum Sualt Arkeoloji Müzesi'nden Bir Grup Mangal Tutacı" Adalya IV, 1999-2000, pp. 61-90. M. R. Leonard, "Braziers in the Bodrum Museum", JA 77, no.1, Jan. 1973, pp. 19-25. U. Wicenciak, "Pottery production in the Late Hellenistic and Early Roman Periods at Jiyeh - ancient Porphyreon (Lebanon)" B. FischerGenz, y. Gerber (eds.), Roman Pottery in the Near East Local Production and Regional Trade Proceedings of the round table held in Berlin, 19-20 February 2010, Archaeopress, Oxford 2014, pp. 103-124, fig.15.

9 For Athenian Agora see. H. R. Robinson, The Athenian Agora V, Pottery of The Roman Period, Princeton, New Jersey 1959, G123.

10 Robinson 1959, p. 35.

11 D. Papanikola-Bakirtzis (ed), Everyday Life in Byzantium, Athens 2002, pp. 548-549.

12 J. S. Crawford, The Byzantine Shops at Sardis, England 1990, fig. 536.

13 J.W.Hayes, "Early Christian Pottery from Knossos: The 1978-1981 Finds from the Knossos Medical Faculty Site", The Annual of the British Schools at Athens, 96, 2001, pp. 431-454, esp.440, A44.

14 P. Reynolds, "From Vandal Africa to Arab Ifriqiya Tracing Ceramic and Economic Trends through the Fifth to the Eleventh Centuries", North Africa Under Byzantium and Early Islam, S. T. Stevens and J. P. Conant (eds), Dumbarton Oaks, 2016, pp. 129-171, fig. 8.18 and 8.19.

15 P. Reynolds, Settlement and Pottery in the Vinalopó Valley (Alicante Spain) A.D. 400-700, BAR 588, Oxford 1993, plate 37, form 97. 
excavations at Yenikapı in İstanbul ${ }^{16}$ show that the use of terracotta braziers continued ${ }^{17}$. The heating vessels made from glazed ceramic and called saltsarion or gararion in the middle Byzantine period may also be evaluated as the continuation of the tradition of these chafing dishes ${ }^{18}$.

Five items belonging to ceramic braziers were determined among the finds from Üstün$1 \ddot{u}^{19}$ and Kurşunlu (Scepsis) ${ }^{20}$. Each of the five items is an example of the semicylindrical type of braziers. The bodies of the artifacts were wheel-shaped. On the other hand, the lugs created to allow the safe placement of the vessel to be placed onto them were shaped by hand. They are units with a slightly incurving upper surface attached immediately to the upper section of the mouth on the edge of the semicylindrical form. It is likely that with the arrangement consisting of the three units placed on both sides and at the center, a plane for placement was obtained for the vessels which would be placed onto the brazier. The diameters were measured as 28 and $24 \mathrm{~cm}$. As the broken items do not provide any complete profile, the heights cannot be determined.

Analogous examples of these braziers, detected with the surveys, resemble the artifacts unearthed during the excavations at the Athenian Agora and dated to the 1st century. With the finds from Thessaloniki, Sardis, Knossos, and Spain, it is understood that the use of the braziers of an analogous type lasted until the 6th century. On the other hand, the pans, cooking pots and stands with a function of cooking that were detected together with the braziers at Üstünlü indicate the 3rd-6th centuries. When the braziers are evaluated together with their analogous examples and the other finds, they can be dated to the early Byzantine period.

16 A. Denker, F. Demirkök, Ö. Korkmaz-Kömürcü, "YK12", Saklı Limandan Hikayeler: Yenikapı'nın Batıkları, İstanbul 2013, 197-209, 202; A. Karamani-Pekin (Ed.). Gün Işı̆̆ında İstanbul'un 8000 yılı Marmaray, Metro, Sultanahmet Kazıları, İstanbul, 2007, p. 224, fig. 16.

17 For a Byzantine stone brazier see. Z. Mercangöz, "İzmir Arkeoloji Müzesi'ndeki Bizans Maltzı", Uluslararası Sanat Tarihi Sempozyumu, Prof. Dr. Gönül Öney'e Armağan, 10-13 Ekim 2001, İzmir 2002, pp. 413-420. In addition for a Ottoman ceramic brazier see. S. Gök, "Osmanlı ve Avrupa Seramikleri Üzerinden Bir Okuma: Smyrna (İzmir) Agorası'ndaki Osmanlı Yerleşiminden Mutfak Kapları ile Günlük Yaşam Objeleri", Smyrna / İzmir Kazı ve Araştırmaları II, İzmir 2017, pp. 132-133, fig 15.

18 For an evalution these vessels see. A. Ç. Türker, "Gelibolu'da Bizans Seramikleri ve Ökaristik Ekmek Damgası", Hacettepe Üniversitesi, Edebiyat Fakültesi Dergisi, 22.2, 2005, pp. 87-104.

19 The place concerned is known as the monastery locality. It is a protected natural port in the Marmara mouth of the Hellespont, see. A. Ç. Türker, "Archaeological Survey of Early Christian - Byzantine Period on the Valleys that Reached the Hellespont: 2010 Research", 29. Araştırma Sonuçları Toplantısı 1. Cilt, Ankara 2013c, 417-418, fig. 15; A. Ç. Türker, "Archaeological Survey of Early Christian - Byzantine Period on the Valleys that Reached the Hellespont: 2016 Research", 35. Araşttrma Sonuçları Toplantısı 1. Cilt, Ankara 2018b, pp.180-182, fig. 9-10.

20 Scepsis (Hagios Kornélios) episcopate in the place concerned is localized on the borders of the Kurşunlu Village in an area overlooking the valley with a narrow flor of the upper Scamander, see. A.C.. Türker, "Bizans Döneminde Çanakkale Boğazı ve Yerleşim Modelleri: Skamander Vadisi", Anadolu ve Çevresinde Ortaçağ 4, 2010, 57-58. 


\section{CATOLOGUE 21 :}

1-The Üstünlü Port. The tile red paste (G10) is heavily and large limestone-tempered as well as moderately heavily and large stone-tempered. Rim diameter: $28 \mathrm{~cm}$, preserved height: $7 \mathrm{~cm}$, wall thickness: $1.5 \mathrm{~cm}$. The left edge fragment of the brazier has been preserved. This section contains a lug which is $3 \mathrm{~cm}$ high on average and which was placed to be located on the edge. It was wheel-made and the exterior face contains grooves.

2. The Üstünlü Port. The red paste (F8) is heavily and large limestone-tempered, moderately heavily and large stone- and chamotte-tempered, and moderately heavily and small mica-tempered. Rim diameter $24-26 \mathrm{~cm}$ ? Preserved height: $10 \mathrm{~cm}$, wall thickness: $0.8 \mathrm{~cm}$. The right edge fragment of the brazier has been preserved and this section contains a lug which is $3 \mathrm{~cm}$ high on average and which was placed to be located on the edge. It was wheel-made and the exterior face contains grooves. However, these grooves on the exterior face are not marked due to the erosion by the sea.

3. The Üstünlü Port. The red paste (F10) is heavily and large limestone- and stone-tempered as well as heavily and small mica-tempered. Rim diameter: $28 \mathrm{~cm}$, preserved height: $7 \mathrm{~cm}$, wall thickness: $0.7 \mathrm{~cm}$. The left edge fragment of the brazier has been preserved and this section contains a lug which is $2 \mathrm{~cm}$ high on average and which was placed to be located on the edge. It was wheel-made.

4. Kurşunlu (Scepsis). The red paste (F10) is heavily and small limestone-, stone-, and mica-tempered. Rim diameter: $28 \mathrm{~cm}$, preserved height: $7.5 \mathrm{~cm}$, wall thickness: $0.6 \mathrm{~cm}$. The left edge fragment of the brazier has been preserved and this section contains a lug which is $1.5 \mathrm{~cm}$ high on average and which was placed to be located on the edge. There is a groove at the rim and it was wheel-made.

5. The Üstünlü Port. The red paste (G9) is heavily and large limestone- and stone-tempered as well as heavily and small mica-tempered. Rim diameter: 26-28? preserved height: $7.5 \mathrm{~cm}$, wall thickness: $0.6 \mathrm{~cm}$. The left edge fragment of the brazier has been preserved and this section contains a lug which is $2 \mathrm{~cm}$ high on average and which was placed to be located on the edge. However, a small portion of the edge fragment of the brazier.

21 "C.E.C Farbkarte shade guide nuancier carta colori" was used for the paste colors in the catalogue. 


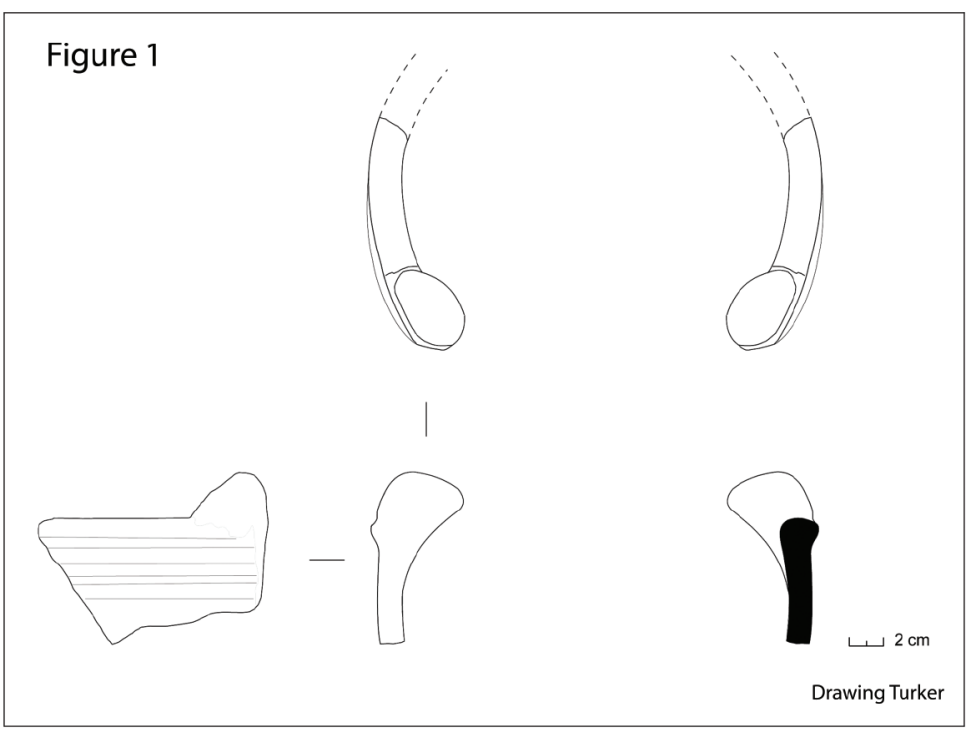

Figure 2
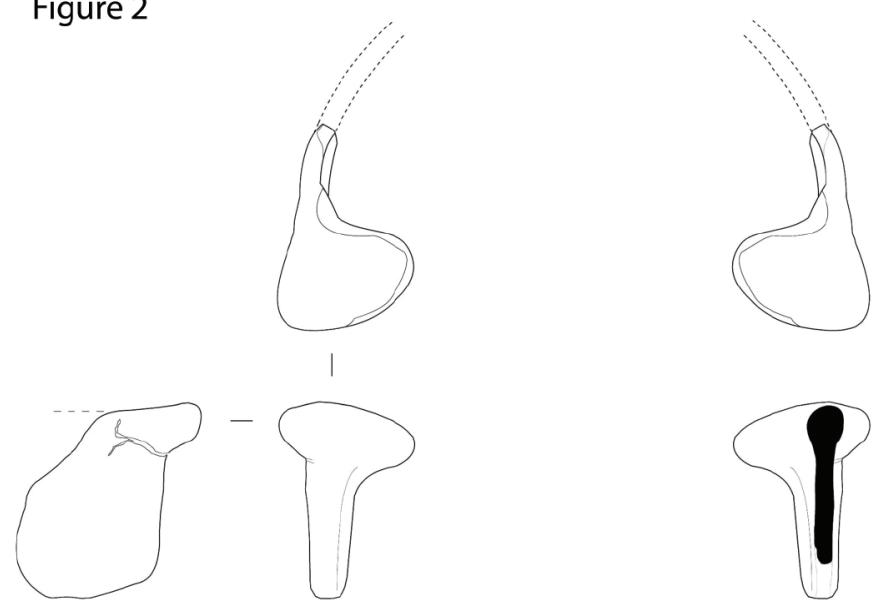

$\llcorner 2 \mathrm{~cm}$ 
Figure 3
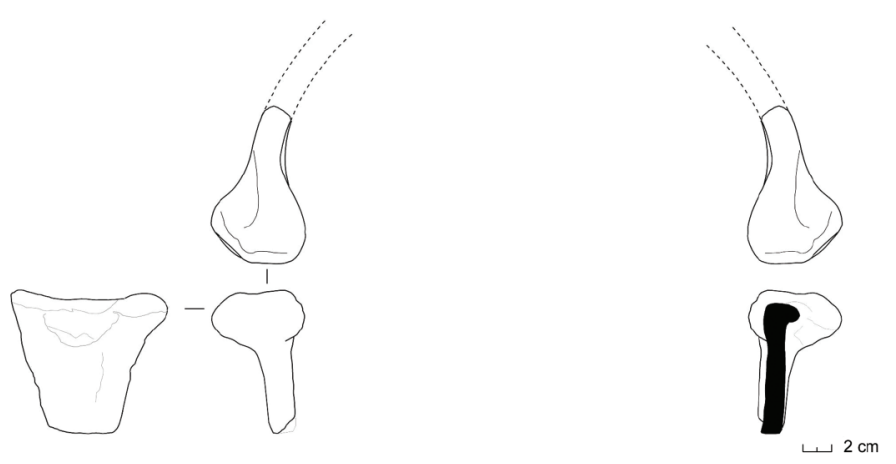

Drawing Turker

Figure 4
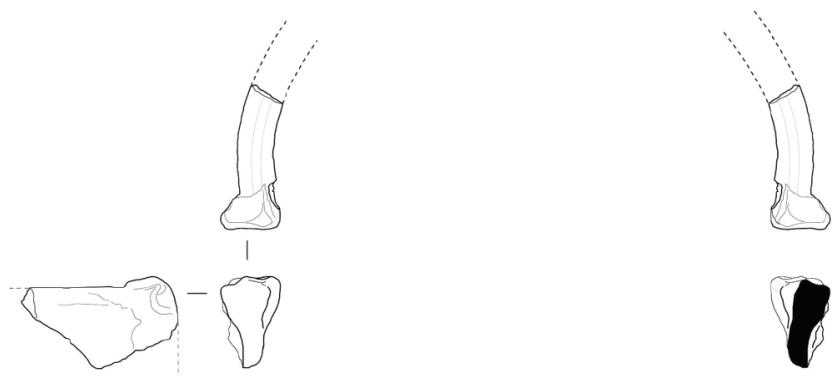

$\leftarrow 2 \mathrm{~cm}$ 
Figure 5

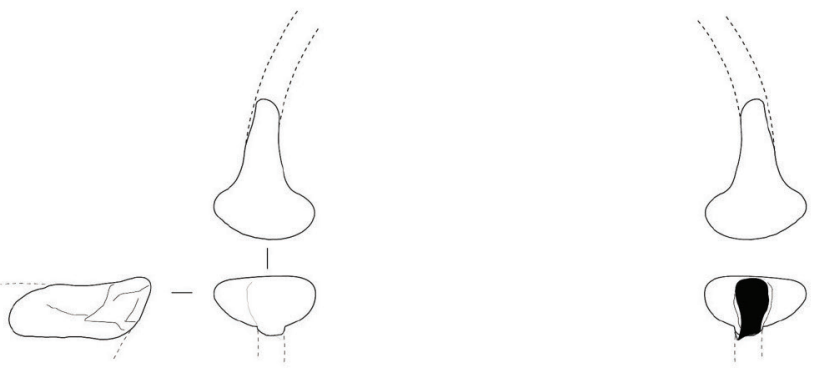

$\llcorner 2 \mathrm{~cm}$

Drawing Turker

Figure 6
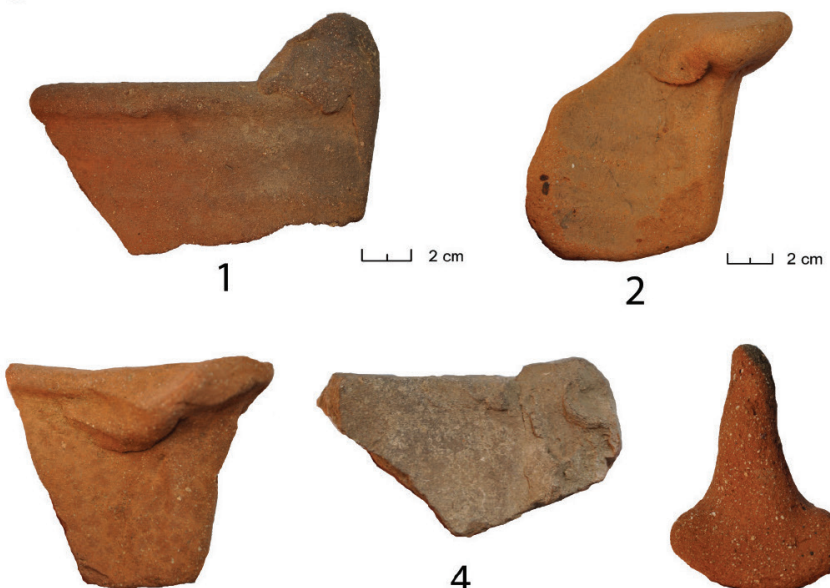

3
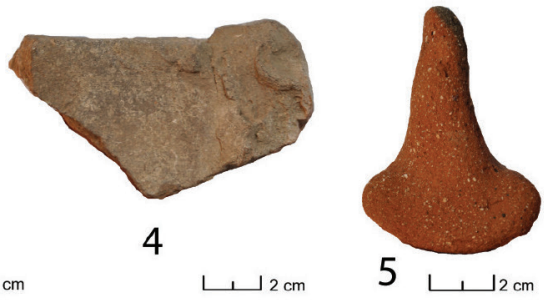


\section{REFERENCES}

Ashkenazi, D. \& M. Fischer \& A. Stern \& O. Tal, (2012). Technology of an ancient ship brazier, a unique example from the southern Levant. Skyllis Vol.12, Heft 1, pp. 85-93.

Aslan, E. (2015). 2014 Yılı Knidos Sualt Araştırmalarında Elde Edilen İlk Bulguların Değerlendirilmesi. Mediterrenean Journal of Humanities, Vol. 1, pp. 101-123.

Aydemir, A. (2005). Funde aus Milet XX. Kochgeschirr und Küchengeräte aus dem archaischen Milet. Archäologischer Anzeiger 2005/2, pp. 85-101.

Crawford, J. S. (1990). The Byzantine Shops at Sardis. England.

Denker, A. \& F. Demirkök \& Ö. Korkmaz-Kömürcü (2013). "YK12", Saklı Limandan Hikayeler: Yenikapı'nın Batkları. İstanbul.

Ekroth, G. (2001). Altars on Attic Vases: The Identification of Bomos and Eschara. Ceramics in context, Proceedindgs of the Internordic Colloquium on Ancient Pottery held at Stocholm, ed. C. Scheffer, pp. 115-126.

Gök, S. (2017). Osmanlı ve Avrupa Seramikleri Üzerinden Bir Okuma: Smyrna (İzmir) Agorası'ndaki Osmanlı Yerleşiminden Mutfak Kapları ile Günlük Yaşam Objeleri. Smyrna / İzmir Kazı ve Araştırmaları II, İzmir, pp. 117-150.

Hayes, J.W. (2001). Early Christian Pottery from Knossos: The 1978-1981 Finds from the Knossos Medical Faculty Site. The Annual of the British Schools at Athens, Vol. 96, pp. 431-454.

Karamani-Pekin, A. (Ed.) (2007). Gün Işığında İstanbul'un 8000 yılı Marmaray, Metro, Sultanahmet Kazıları, İstanbul.

Kern, J. H. C. (1958). A Roman Terra Sigillata Dish From Tunisia, in Leyden. Mnemosyne, Fourth series, Vol. 11, Fasc. 2, pp. 152-156.

Leonard, M. R. (1973). Braziers in the Bodrum Museum. JA 77, no.1, pp. 19-25.

Mercangöz, Z. (2002). İzmir Arkeoloji Müzesi'ndeki Bizans Maltzı. Uluslararası Sanat Tarihi Sempozyumu, Prof. Dr. Gönül Öney'e Armağan, 10-13 Ekim 2001, İzmir, pp. 413-420.

Mingazzini, P. (1930). Vasi della colleziione Castellani. Catalogo. Rome.

Naumann, R. (1991). Eski Anadolu Mimarlığı, Ankara.

Papanikola-Bakirtzis, D. (Ed) (2002). Everyday Life in Byzantium, Athens.

Pieraccini, Lisa C. (2003). Around the Hearth, Caeratan Cylinder Stamped Braziers. Roma.

Radt, W. (1982). "Pergamon Vorbericht über die Kampagne 1979. TürkAD Vol. 26-1, pp. 11-25.

Reynolds, P. (1993). Settlement and Pottery in the Vinalopó Valley (Alicante Spain) A.D. 400-700. Oxford.

Reynolds, P. (2016). From Vandal Africa to Arab Ifriqiya Tracing Ceramic and Economic Trends through the Fifth to the Eleventh Centuries. North Africa Under Byzantium and Early Islam, S. T. Stevens \& J. P. Conant (eds), Dumbarton Oaks, pp.129-171.

Robinson, H. R. (1959). The Athenian Agora V, Pottery of The Roman Period, Princeton, New Jersey.

Snodgrass, M. E. (2004). Encyclopedia of Kitchen History, New York.

Sparkes, B. A. (1962). The Greek Kitchen, JHS, Vol. 82, pp.121-137,

Şahin, M.( 1999-2000). Bodrum Sualt Arkeoloji Müzesi'nden Bir Grup Mangal Tutacı. Adalya Vol. IV, pp. 6190.

Türker, A. Ç. (2005). Gelibolu'da Bizans Seramikleri ve Ökaristik Ekmek Damgası. Hacettepe Üniversitesi, Edebiyat Fakültesi Dergisi, Vol. 22.2, pp. 87-104.

Türker, A.Ç. (2010). Bizans Döneminde Çanakkale Boğazı ve Yerleşim Modelleri: Skamander Vadisi, Anadolu ve Çevresinde Ortaçağ 4, pp.53-94.

Türker, A. Ç. (2013a). Byzantine Pottery from Dardanos and Kepez in the Hellespontus. The Deltion of the Christian Archaeological Society,33, pp. 361-374;

Türker, A. Ç. (2013b). Two Byzantine Cities in the middle section of the Dardanelles: Madytos and Koila. Episcopus, ciuitas, territoriumunun, Città del Vaticano 2013, Acta XVth. International Conggressvs Internationalis Archaeologicae Cristianae, Toledo, 8-12.9.2008 (Ed. O. Brandt -S. Cresci, J. López Quiroga- C. Pappalardo), Città del Vaticano, pp. 105-119.

Türker, A. Ç. (2013c). Archaeological Survey of Early Christian - Byzantine Period on the Valleys that Reached the Hellespont: 2010 Research, 29. Araştrrma Sonuçları Toplantisı 1. Cilt, Ankara. pp. 401-428.

Türker, A. Ç. (2018a). Byzantine Pottery from the Pegai Castle. Xtth Congress AIECM3 on Medieval and Modern Period Mediterranean Ceramics Proceedings, 19-24 October Antalya. Vol 1, pp. 371-382. 
Türker, A. Ç. (2018b). "Archaeological Survey of Early Christian - Byzantine Period on the Valleys that Reached the Hellespont: 2016 Research", 35. Araştrma Sonuçları Toplantisı 1. Cilt, Ankara. pp. 177-188.

Türker, A. Ç. (in print). Çanakkale Boğazı ve Çevresindeki Bizans Limanları: Üstünlü Limanı. Uluslararası Propontis ve Çevre Kültürleri Sempozyumu, Tarihöncesi Çağlardan Antik Dönem Sonuna Kadar, 1519 Ekim 2018, Biga- Çanakkale.

Türker, A. Ç. (in print). Stands From Üstünlü Port, LRCW 6, 6th International Conference on Late Roman Coarse Ware, Cooking Ware and Amphorae in the Mediterranean: Archaeology and Archaeometry Land and sea: pottery routes, Agrigento, 24-28 maggio 2017.

Türker, A. Ç. (in print). Byzantine Pottery From Hexamilion on the Thracian Chersonese. AIECM 3, $12^{\text {th }}$ Congress on Medieval and Modern Period Mediterranean Ceramics, 21-27 Ekim 2018. Atina.

Wicenciak, U. (2014). Pottery production in the Late Hellenistic and Early Roman Periods at Jiyeh - ancient Porphyreon (Lebanon). Roman Pottery in the Near East Local Production and Regional Trade Proceedings of the round table held in Berlin 19-20 February 2010. B. Fischer-Genz \& Y. Gerber (eds.), Oxford. pp. 103-124. 